\title{
Horizon of Expectation on Popular Lyrical Poetry: Jauss's Reader Response Perspective
}

\author{
Alfa Ghifari ${ }^{1}$, Budi Tri Santosa ${ }^{2}$, and Diana Hardiyanti ${ }^{3}$ \\ ${ }^{1,2,3}$ Universitas Muhammadiyah Semarang, Indonesia \\ (btsantosa@unimus.ac.id)
}

\begin{abstract}
Humans have various opinions in commenting on a literary work. This diversity of opinions will eventually participate in developing research in the literary world. Lyrics are a medium for an author to convey the message he wants to convey in a more free and elegant form. This study aims to describe the reader's perception of the messages and values contained in the lyrics of Rebel's Girl from Bikini Kill, Beyoncé from Partition, and God Is a Woman from Ariana Grande. This study uses Jauss' theory of the Harapan Horizon where the role of the reader is the main key in conducting an investigation of a literary work. This research is a qualitative descriptive literature research using a questionnaire distributed to readers who are used as respondents. Respondents were selected randomly with the aim of knowing the differences in opinion of each respondent in responding to a literary work. The conclusion of this study is that the various opinions obtained are influenced by the diversity of backgrounds of the respondents such as differences in gender, age, level of education and experience. In addition, there are messages obtained by readers through the lyrics, namely; freedom of speech, feminism, inner beauty, and sex education.
\end{abstract}

Keywords: Collaborative; learning community; lesson study.

Literary research generally only focuses on examining the intrinsic elements that exist in a literary work. This is indicated by the number of literary research journals that mostly examine more deeply what is contained in a literary work. The general thing to study is the intrinsic and extrinsic elements contained in a literary work (Klarer, 2004). The research focuses on the literary work itself, with the aim of finding out what message the author wants to convey through the literary work. This is also supported by the many discussions or conversations in the community about admiring a literary work.. Therefore, this research focuses on reader response toward lyrical poetry..

At present, reader has an important role in the development of a literary work. So far, readers have only had a few places in literary studies. This is usual, considering that the reader is the most ambiguous element that is almost undefined. Moreover, readers are often considered as objects or consumers of a

How to cite (in APA style):

Ghifari, A, Santosa, B.S., \& Hardiyanti, D. (2021). Horizon of Expectation on Popular Lyrical Poetry: Jauss's Reader Response Perspective. English Language, Literature, and Teaching, 6(2), 55-69 doi: 10.32528/ellite.v6i2.6088 
literary work (Adi, 2011). Therefore, it is not so surprising to ignore this perception about reader. The presence of literary works in society cannot be separated from the role of readers as consumers of literary works, not only that, literary works will truly become literary works if the work reaches the reader, is enjoyed and accepted as a literary work. For this reason, the role of the reader in literary works is very necessary, even absolute.

The neglection of the reader's role is mentioned in the traditional communication chain. This communication chain assumes that communication is only unidirectional and also determinant. Indication of the reader at the end of communication indicates that the reader is not taken into account and is even seen as having no contribution. There are still few researchers who focus on readers of literary works because all of them focus on the text contained in a literary work. The role of the reader who does not know anything about the creative process plays an important role in research, because it is the reader who enjoys, evaluates, and makes use of literary works, even writers who know the intricacies of their work are not considered to exist (Adi, 2011).

The existence of the author and literary works is certainly never separated from the reader. This is because the three of them have an inseparable relationship, especially the relationship between the author and the reader by making literary works as a means of connecting. Readers are recipients of literary works with various interpretations according to their views based on their experience and knowledge (Tyson, 2006). In this case, there is an indirect communication interaction relationship between the author and the reader.

Readers have an important role in the world of literature. A work without a reader is nothing more than a collection of manuscripts. Nowadays, the emergence of literary works is increasing. The existence of literary works, cannot be separated from the expertise of a writer in exploring his ideas. In literature, writers-readers are the link in moving the development of literary works. The author is the starting point in the existence of literary works. This literary work will be accepted by the reader.

Readers have the freedom to analyze a work. Each reader has a different understanding and interpretation, because literary texts are a study of interpretation (Endraswara, 2008). Various kinds of readers' understanding of the work, one of which can be seen from the reader's expression. There a various expression in reading a poetry. One poem has different variations, according to the reader's understanding. Some read poetry aloud, with emotion and anger, some read in a soft voice using sad expressions and shedding tears. Likewise with the prose genre, how the reader explores the psychological conflicts of the characters in the work and their social circumstances. Readers indirectly, as if participating in the conflict that occurred. The presence of readers helps the development of literature.

Every reader of a literary work, basically, the reader has acted as a critic, because the reader can judge whether the literary work is interesting or not (Endraswara, 2008). The position of the reader has an important place in literary research. Its existence contributes to the development of literature. Literary studies are no longer focused on the text, but are able to explore its external elements (readers, authors and social elements in it). In addition, the reader is the jury in assessing a work. If no one reads the literary work, the literary function has no role in the work. Therefore, the role of reader to respond literary works is fundamental.

Reader response is not a conceptually bound together basic position. Its hypothesis is instep related with the work of pundits who utilize the perusing prepare and response to centralize the method of elucidation. The interpretive prepare portrays the author's state of mind towards the reader, categorizes sorts of readers, and how diverse readers 
reach the meaning and the connection of perusing traditions to the writings beneath talk. The status of a literature is examined in connection to its objectivity (Adi, 2011). It is contended that a literature cannot be objective. Composing and perusing are the same action, and scholarly reaction may be a result of impact; in this manner, the treatment of a literature as an objective undertaking does not legitimize the point of scholarly feedback. The meaning of the literature is fragmented without the reader's revaluation. The unmistakable address is how distant a literature decides its claim meaning and how distant is the meaning decided by the reader.

In this research, researcher use Reception Theory by Hans Robert Jauss. Jauss; 1970 explains the acceptance aspect in this case how a writer accepts his previous work, which allows him to create something new from it, or how a non-creative writer accepts a work so that the work has a certain meaning for him (Pradopo, 2007). In essence, it focuses on the activeness of the reader to their ability to use imagination in the reading process. Jauss understands literary works can be seen from their statements. This statement may be in the form of comments or in the form of other essays that transform or demystify the essays that he has read. Jauss's approach provides a framework for literary development because his approach develops attention to the activity of the reader.

In this research, the researcher is interested in analyzing the reader's reception particularly about believes in a lyric. The lyric is chosen as an object of this research because the lyric is used as a reflection of the life in society. Besides, it refers to the intrinsic elements of the literary works but it also on social issues.

In this research, the researcher will use three lyrics by different singer. The first lyric is Bikini Kill by Rebel's girl, Partition by Beyoncé, and God Is A Woman by Ariana grande. Those lyrics are chosen because they are contemporary work and considered as feminist essence. Another reason is that the singers concern about feminist issues. Rebel Girl was created in 1991 and released in 1993. This lyric is often seen as a manifesto of women who want to rebel and make a social revolution. Partition is lyric that actually considered to neglect traditional women norm as no one. While God is A Woman is Ariana Grande's lyric that shows that women can hold the world.

The statement of problems arisen in this research, therefore the aims of this research would be 1)To identify reader's reception to lyrics Bikini Kill's by Rebel's Girl, Partition by Beyoncé, and God Is a Woman by Ariana Grande, 2) To identify values contained in Bikini Kill's by Rebel's Girl, Partition by Beyoncé, and God Is A Woman by Ariana Grande lyric according to reader reception.

There are several researches that are related to this research in terms of the object being analysis. Among those researches, there are two most related researches. One of the related research is from Desi Kusumawati, 2019, Universitas Negeri Surabaya, with the title "Estetika Resepsi Dalam Novel Cantik Itu Luka Karya Eka Kurniawan; Kajian Hans Robert Jauss". The theory used is Hans Robert Jauss's aesthetic reception. This theory is used to analyze the questionnaire data in accordance with Hans Robert Jauss' theory based on the reader's experience with the novel, horizon of hope, aesthetic distance, spirit of the times, literary series and literary history in the novel Cantik Itu Luka by Eka Kurniawan. The results show that understanding and meaning are based on the reader's experience, horizon of hope, aesthetic distance, spirit of the times, literary series and literary history experience differences in the novel Cantik Itu Luka. (Kusumawati, 2019)

The second previous research is from Lusi Nurkhayati, 2018 Universitas Muhammadiyah Semarang, with the title "Analysis of Spike Lee's Malcolm X (1992) : The Intrinsic Aspects and the Reader's Responses to the Movie". In this research, the researcher used literature study to obtain information and research data also observe the reader's 
responses. The researcher used hermeneutic theory with structural approach and reader response approach. Lusi Nurhayati focused on the concept of human transformation to Islamic point of view (Lusi Nurhayati, 2018).

The third of previous research that the researcher chosed was from Satriya Wibowo, 2018 Universitas Islam Negeri Sunan Kalijaga Yogyakarta, with the title "You'll Never Walk Alone Song: Reader Response Analysis". In this research, the researcher used literature study to obtain information and research data also observe the reader's responses. For the analysis he used the theory of Wolfgang Iseer. The goal points are to find out the interaction between content, reader, and reactions in perusing prepare by utilizing phenomenology approach and phenomenology worldview. Substantively, the viewpoints are affected by the readers background that comes from distinctive level instruction, sexual orientation, and encounter (Satriya Wibowo, 2018).

Based on the three previous studies above, the research compiled by the author has differences. The difference is the researcher use of the seven theses theoretical thinking from Hans Robert Jauss in compiling the research. In addition, the respondents in this study are readers who have a study background in English literature so that they can produce comprehensive results. It is hoped that this research can add discussion points in the application of expectation horizon analysis according to Jauss' perspective.

\section{Horizon of Expectation}

Relation between the reader and the literary text causes a process of interpretation of the text by the reader as an objective, the result of which is the recognition of the meaning of the text (Nuryatin, 1998). In responding to literary works, readers always form aesthetic elements through the encounter between horizons expectations, text forms, and norms in literature.

The expectation horizon is determined by a person's level of education, experience, knowledge and ability in responding to a literary work. The reader as the giver of meaning will always be determined by space, time, social group, culture and experience (Jauss in Nuryatin 1998: 133). Acceptance of literary works in society can occur with various possibilities. The reaction or active participation occurs in the form of people who create other literary works. This reaction is different from passive acceptance which is only commenting, liking, criticizing and providing input on the literary work.

Jauss' literary reception theory approach emphasizes the acceptance aspect in this case how a creative writer accepts his previous work, which allows him to create something new from it, or how a non-creative writer accepts a work so that the work has a certain meaning for him (Jauss, 1983). This theory focuses on the activeness of the reader to their ability to use imagination in the reading process. Jauss understands literary works can be seen from their statements. This statement may be in the form of comments or in the form of other essays that transform or demystify the essays that he has read. Jauss's approach provides a framework for literary development because his approach develops attention to the activities of the reader, not just impressions as assumed by Iser.

Reception theory, which is a historical application of reader response, was especially developed in Germany when Hans Robert Jauss published an article entitled Literary Theory as a Challenge to Literary Theory (1970). The focus of his attention, like other reader response theories, is the acceptance of a text. His main interest is not in the response of a particular reader at a certain time but in the changes in the interpretation and evaluation of the general reader's response to the same text or different texts at different times.

According to Jauss (1983: 13) the main concern in literary theory is the reader of literary works among the triangular fabric of the author, literary works, and the reading community. The reader has an active role and 
even has the power to shape history. In the view of Jauss (1983: 12) a literary work can be accepted at a certain time based on a certain expected acceptance horizon.

Horizon of Expectation was introduced by Jauss to explain the criteria used by readers to consider literary texts in a certain period. The horizon of expectations is determined by the level of education, experience, knowledge and ability of a person in responding to a literary work. According to Segers (in Pradopo 2007) the horizon of expectation is determined by three criteria, first, it is determined by the norms emanating from the texts that have been read by readers. Second, it is determined by knowledge and experience of all texts that have been read before. Third, the conflict between fiction and reality, namely the ability of the reader to understand, both within the narrow horizon of literary expectations and in the broad horizon of his knowledge of life.

According to Segers (in Pradopo 2007), Jauss expresses seven theses of his theoretical thinking. Briefly, the seven theses are as follows

a. Literary works are not monuments that express one and the same meaning, as is the traditional assumption of historical objectivity as closed descriptions.

b. The horizon system of readers' expectations arises as a result of the historical moment of a literary work, which includes a preunderstanding of genres, forms, and themes in familiar works, and from an understanding of the opposition between poetic language and everyday language.

c. If it turns out that there is still an aesthetic distance between the horizon of hope and the form of a new literary work, then the acceptance process can change that expectation either through denial of a known aesthetic experience or through the realization that a new aesthetic experience has emerged.

d. Reconstruction of the horizon of hope for literary works from the time they were created or welcomed in the past to the present, will produce various variants of reception with the spirit of a different era.

e. The aesthetic theory of acceptance does not merely understand the meaning and form of literary works according to historical understanding.

f. If the understanding and meaning of a literary work according to historical reception cannot be done because of a change in aesthetic attitude, then one can use a synchronic perspective to describe similarities, differences, contradictions, or the relationship between contemporary art systems and art systems in the past.

g. The task of literary history does not become complete only by presenting systems of literary works synchronously and diachronically, but must also be related to general history.

\section{Method}

As for the method, this research is field research. Field research is a research in which the data source comes from the respondents or those who listen the lyric (Sugiyono, 2012). This research is qualitative descriptive research. Qualitative research is utilized to get it and translate social conduct and human because it is live by members in a specific social setting (Ary, Jacobs, Sorensen and Razayieh, 2010). To obtain this data source, the researcher used communication method with questionnaire technique. Based on the method of data processing, this type of research is qualitative descriptive research.

Qualitative descriptive kind is the foremost fitting when a clear portrayal of the marvel is crave. According to Lambert (2012:256), this kind of research is about contains with respect to an occasion, who was included, what was included, and where did things take places within the prepare of the research. Based on the explanation above, the use of qualitative descriptive kind of research is suitable to finish this reader response research dealing with the lyrics Bikini Kill's Rebel's Girl (1991), Beyoncés Partition (2013), Ariana 
Grande’s God Is A Woman (2018).

\section{Technique of Data Collection}

Technique of data collection was a way by the researcher in collecting the data (Usman, 2008). This data collection aims to obtain the information needed to achieve the objectives of the researcher. This research used questioner to collect the data. A Questionnaire was a research tool consisting of a collection of questions that were used as a references material to get responses from selected groups of people through inteview or questionnaires (Sugiyono, 2008).

This research used an open questionnaire type with an electronic questionnaire. This was used to collect data from respondents (Sugiyono, 2008). Respondents in this research were some random selected people. The selection of random selected people as respondents is to find out their knowledge about the role of women in the social order through the lyrics to be analyzed.

In performing data collection, there were several steps that must be done by the researcher. There were 4 steps in collecting the data, they were: (i) the researcher made questionnaire related to the problems, especially dealing with the reader's reception. Questionnaire is needed to explore and exspose reader perception. For example question such as how do you as reader perceipt those lyrical poetry as feminist value? (ii) The researcher gathered the respondents by online forms. They were observed the lyric Bikini Kill by Rebel's Girl, Partition by Beyoncé, and God Is A Woman by Ariana Grande. (iii) The researcher distributes a questionnaire to the readers after reading the lyric Bikini Kill's by Rebel's Girl, Partition by Beyoncé, and God Is A Woman by Ariana Grande. (iv) The researcher collected a questionnaire containing the reader's response data which was then described with the theory of Jauss Perspective approach.

\section{Technique of Data Analysis}

There are two techniques to analyze the data in this research. Each technique is used to analyze every problem that exists in this research. They are:

a. Analysis of reader response taken from the reader conducted after analyzing the literatures. This section consists of more specific steps. The first is to categorize the reader's perceptions. The second is to categorize the type of readers. The third is analyzing the differences in reader perceptions.

b. In this research, the researcher uses descriptive method as a method of data analysis. According to Whiney in Asep Saepul (2014), descriptive method is the search for a fact with the right interpretation. Descriptive research studies the problems in society, the procedures that apply, certain situations including about relationships, activities, attitudes, views and ongoing processes and the influence of a phenomenon (Saepul, 2014).

\section{Results and Discussion \\ Reader Reception to lyrics in Rebel's Girl by Bikini Kill, Partition by Beyoncé, and God Is a Woman by Ariana Grande}

Based on the data obtained, readers have various opinions on the contents contained in the lyrics. This can be shown by the factors that influence the reader in interpreting a lyric. Differences in level of education, gender, and experience are the keys to differences in reader responses in a work. Here are the reader reception to lyrics in Rebel's Girl by Bikini Kill, Partition by Beyoncé, and God Is a Woman by Ariana Grande:

Based on the answers collected, there are 12 respondents (87\%) who believe if lyrics in Rebel's Girl by Bikini Kill, Partition by Beyoncé, and God Is a Woman by Ariana Grande convey about woman struggle towards society. This data proves that according to the reader, there are problems that arise in gender equality. According to the reader, the lyrics contained in Rebel's Girl by Bikini Kill, 
Partition by Beyoncé, and God Is a Woman by Ariana Grande try to convey the desire of women to make a change in values in everyday life.

Mostly, 12 respondents (80\%) who believe if lyrics in Rebel's Girl by Bikini Kill, Partition by Beyoncé, and God Is a Woman by Ariana Grande convey about woman struggle towards society is a person who support gender equality with various age backgrounds from 21 - 47 years old. Even so, there is one respondent at the age of 17 who does not support gender equality. This can happen because most people in their teens do not really understand about gender equality. So with this data, understanding of gender equality should be taught more intensively at the high school level. This is important so that women can understand the nature and roles they can take in the future without having to deal with gender inequality.

Furthermore, there are 3 respondents (20\%) who don't believe if lyrics Rebel's Girl by Bikini Kill, Partition by Beyoncé, and God Is a Woman By Ariana Grande try to convey woman struggle. This proves that gender equality is not only based on aspects of freedom of opinion, wealth, and leadership.

Differences in roles, functions and duties of men and women are not a problem as long as no one is harmed. Injustice or gender inequality occurs when someone is treated unfairly based on their gender. When someone does not have the opportunity in the same benefits just because of different gender, it would make gender inequality problem.

The role of women who are only underestimated as weak creatures is broken in the lyrics. Women are also believed to be able to set a policy. In addition, women also have the right to express opinions in various aspects. Women also have more intelligence so they are believed to have abilities that are not inferior to men. This appears in the following snippet of lyrics.

A1 :That girl thinks she's the queen of the neighborhood

A2 :She's got the hottest trike in town

A3 :That girl, she holds her head up so high

A4 :I think I wanna be her best friend, yeah

A5:Rebel girl, rebel girl

A6:Rebel girl you are the queen of my world

Queen is a title of nobility in the world that can refer to two things, the woman who leads the kingdom or the wife of the king. The title is commensurate with the title as King. In the context of being a monarch, the queen's territory is called a kingdom. Based on this description, it can be seen that the queen has an important role in regulating the order of a government.

Based on the answer collected, there are 12 respondents (80\%) who believe if lyrics Rebel's Girl by Bikini Kill conveys about woman revolution about social status. Mostly, 10 respondents comes from people who doesn't believe if woman are weak social creature. They also believe if woman already have a privilege in social life. So, being a leader of a community isn't something wrong if they looked forward into the lyrics.

While 3 respondents (20\%) who don't believe if lyrics Rebel's Girl by Bikini Kill conveys about woman revolution about social status are male. Three of them are totally support patriarchy norms. Respondents believe that woman can't live without role of man. Beside that, being a leader as a woman The physical limitations and scope of movement that women have is believed to be the reason that women are weak. Men are created with physically stronger conditions and women are a level below him, this makes the attitude towards a female leader will be different from that of a male leader.

Gender Inequality can be formed in many condition, such as if one gender is lower than the other, so it does not get the same value as the other gender. Education for men is preferred because of the assumption that sons are superior, continue the family line, daughters will only be in the kitchen after marriage. This causes women to not develop. 
In addition, women cannot have the knowledge to make decisions for themselves. As a result, women will depend on their husbands. And, when the husband dies, for example, the woman does not have the skills to support her life and that of her children, and will continue to be entangled in the cycle of poverty.

With so many cases leading to gender inequality, many feminist movements have emerged. One proof is reflected in the lyrics of Rebel's Girl by Bikini Kill through the following lyric:

A10: When she talks, I hear the revolution A11: In her hips, there's revolution

A12: When she walks, the revolution's coming A13: In her kiss, I taste the revolution

In the lyrics above, it can be proven that women can make a change in social life. Revolution can also be achieved with the role of women. Through passion, action, and movement, a revolution can arise.

Based on the answers collected, there are 12 respondents (87\%) who believe if lyrics in Rebel's Girl by Bikini Kill talked about woman revolution. After reading the lyrics, respondents believed that the lyrics were about a group of women who wanted a revolution. Feminist movement more progressive, where this understanding does not only contain criticism of the patriarchy system, but rather on the recognition and positive attitude towards the needs of women as a group. In this case, feminism can be defined as an awareness of the oppression and exploitation of women in society, at work and in the family, as well as conscious actions by women and men to change unfair conditions.

There are 3 respondents who doesn't believe who believe if lyrics in Rebel's Girl by Bikini Kill talked about woman revolution. Based on their backgrounds, three respondents are male and they still support norms of patriarchy. Mostly the patriarchal social system makes men have special rights over women. Their dominance does not only cover the personal realm, but also in a wider realm such as political participation, education, economics, social, law and others. Not infrequently patriarchy actually causes problems. On the basis of the privileges possessed by men, there are many cases of harassment and acts of violence perpetrated by men against women.

Women also have limitations in terms of personality. Women are believed to be too focused on beauty, elegance, and tenderness. In contrast to the personality that must be owned by a leader. assertiveness, courage, and responsibility are often more visible in the personality of a man. This explanation shown in below lyrics.

\section{A8:I think I wanna take you home \\ A9:I wanna try on your clothes, uh}

The lyrics above can be the reason why women are believed to not have sufficient ability to become a leader. Women just want to talk about clothes at home with friends rather than talking about bigger issues. The big things that are meant are talking about the role of the government, the state debt, or other complicated issues. Rebellion by women is also not necessarily a good thing and can lead to a revolution. It could be that rebellion is just a fad that a group of women do to get what they want.

Another of that, there are 11 respondents (73\%) who believe if lyrics in Rebel's Girl by Bikini Kill convey about women activist solidarity. Based on backgrounds data, all 11 respondents support gender equality. They are at age $21-47$ years who definitely already know and understand many value contained in gender equality. Moreover, at that age people already can get the information more. Because they can access it on internet, and at that age they also can filter the information they get. So, they can find which information that is contain good value. One proof is reflected in the lyrics of Rebel's Girl by Bikini Kill through the following lyric: 
A28: Love you like a sister always

A29: Soul sister, rebel girl

A30: Come and be my best friend

A31: Will you, rebel girl?

A32: I really like you

A33: I really wanna be your best friend

A34: Be my rebel girl

Those lyric not only talk about a friendship, but it also talked about woman activist solidarity. Again, feminist movement isn't only initiated and can be done by a person only. Feminist movement can be done and being reached because there is a struggle among women who wants a same thing. 11 respondents $(73 \%)$ who believe if lyrics in Rebel's Girl by Bikini Kill convey about women activist solidarity basically they believe that woman not only do housework. They believe that woman can do such great movement if they do it together. With whole woman spirit, women are not weak social creature like the respondent belong it too.

While, there are 4 respondents (27\%) who doesn't believe if lyrics in Rebel's Girl by Bikini Kill convey about women activist solidarity. Basically, their response is belongs to a physical power by a woman. Respondent who don't believe if lyrics in Rebel's Girl by Bikini Kill convey about women activist solidarity are male. They believe if woman doesn't have much physical power to do such a demonstration and make a revolution. Women still needs men to do big movement.

In this era, right to love and to be loved is more important. The freedom to express what they feel becomes a new benchmark for women. Regarding lyrics in Partition by Beyoncé, there are 13 respondents (87\%) who believe if lyrics in Partition by Beyoncé convey that women can say love like a man. One proof is reflected in the lyrics of Partition by Beyoncé through the following lyric:

B4 :See me up in the club with fifty-eleven girls $B 5$ :Posted in the back, diamond fangs in my grill B6:Brooklyn brim with my eyes sittin' low
$B 7$ :Every boy in here with me got that smoke $B 8$ :And every girl in here got to look me up and down $B 9:$ All on Instagram, cake by the pound B10 :Circulate the image every time I come around

B11:G's up, tell me how I'm lookin' babe

Through lyrics above, it can be proven that women can get all what they want including love. Wealth, attention, even women can commit acts of sexual harassment even if it's just a snap of a finger or a wink at a man. Expressing feelings in words, both spoken and written, is the simplest way to show affection. However, it turns out that not all women can do it easily. In fact, expressing our feelings to others, whether to partners, friends, or family is important.

While 2 respondents who disagreed if lyrics Partition by Beyoncé convey that women can say love like a man is officially can be accepted. Confidence to convey feelings is different for each person. Somehow, saying love isn't only through words and lyrics. Because there is still a love language that is well known in the community, namely, giving quality time, praise, service, gifts or touch.

Assumption that women have to be beautiful to get attention is a mistake. The assumption narrows that women who are not beautiful will not get good grades in society. This expression also appears in the lyrics Partition by Beyoncé below.

B12:Boy this all for you, just walk my way

B13:Just tell me how it's lookin' babe, just tell me how it's lookin' babe

B14:I do this all for you baby just take aim B15:And tell me how it's lookin babe, and tell me how it's lookin' babe

\section{B16:Lookin' babe}

From lyrics above, we can get clear enough assumption if woman just need to be what men want. There are 8 respondents (53\%) who agree if lyrics Partition by Beyoncé convey that being woman must good at dressing 
up to attract a men. 4 respondents of them are male. This is normal for men. Because judging women from physique and beauty is the simplest thing to choose a woman before becoming a partner. While 4 female respondents who agree if lyrics Partition by Beyoncé convey that being woman must good at dressing up to attract a men isn't a mistake. This can be based on the fact that beauty is a gift from God. Every woman is required indirectly to maintain and care for her beauty as a form of gratitude to her god.

While there still 7 respondents (47\%) who doesn't agree if lyrics Partition by Beyoncé convey that being woman must good at dressing up to attract a men. 5 respondents are female that officially don't married yet and they are around 17 - 23 years old. This shows that today's teenager also believe in the power of inner beauty. So that in any level of beauty a woman will look attractive if she can show another side that can make people wants to notice her.

The courage of women in terms of sexual behavior also began to emerge. Many cases reveal that women commit a deviant harassment. Sexual harassment is a common thing that is done by women. Indirectly, this becomes a belief that women also have a sexual desire that is no less high than that of a man. The evidence in accordance with the description is as follows.

B17:Drop the bass, mane, the bass get lower B18:Radio say speed it up I just go slower B19:High like treble, pumping on them mids B20:Ya man ain't never seen a booty like this B21:And why you think ya keep my name rollin' off the tongue

B22:'Cause when he wanna smash, I'll just write another one

B23:I sneezed on the beat and the beat got sicker B24:Yoncé all on his mouth like liquor

Based on data obtained, there are 11 respondents (73\%) who believe if lyrics Partition by Beyoncé convey that woman can do sexual harassment too. Most of the respondents who agree aren't believe if woman is weak social creature. Even though it's just catcalling, it can also be sexual harassment especially oral harassment. Harassment can occur because there are person who feel psychologically harmed. Catcalling can make the victim uncomfortable with the conditions that arise. This discomfort can cause the victim to become afraid of the perpetrator and become uncomfortable to meet with the opposite sex.

While 4 respondents (20\%) who doesn't believe who believe if lyrics Partition by Beyoncé convey that woman can do sexual harassment too are respondent who support gender equality. In gender equality, men and women have an obligation to look after and protect each other. Protecting the dignity and worth, to maintaining the honor of the opposite sex must be done by everyone. That way, people will be aware of the importance of maintaining the way they behave with the opposite sex. So that, the occurrence of sexual harassment can be minimized.

Freedom of expression for women is important. The aim is to underline and pay special attention to the issues faced by women, while at the same time fighting for gender equality. Because, there are so many inequalities they face, ranging from access to education, health, to protection from all forms of violence.

Freedom of expression for women, massive feminist movements, and fair environment through government will hold up value for gender equality. Gender inequality in opportunity and control over resources, the economy, power, and political participation are ubiquitous. Women bear the brunt of the inequalities that occur, but basically, inequality is detrimental to everyone. Therefore, gender equality is the main issue of a development goal for universe through good government. A proof is reflected in the lyrics of God Is a Woman by Ariana Grande through the following lyric: 
C1 :You, you love it how I move you

C2 :You love it how I touch you

C3 :My one, when all is said and done

C4 :You'll believe God is a woman

C5 :And I, I feel it after midnight

C6 :A feelin' that you can't fight

C7 :My one, it lingers when we're done

C8 :You'll believe God is a woman

Based on data obtained there are 12 respondents (87\%) who believe if lyrics in God Is a Woman by Ariana Grande try to convey that women be a leader of universe. Through the lyrics above, it can be proven that women also can be a leader. Women can have everything including being a leader in front of their people. Women can become leaders who are respected by their people with their skills in regulating a life order.

Those respondents believe if women already have privilege in society. This can strengthen the opinion that women can also be considered for their ability to lead a country and bring the justice. They don't believe if woman is a weak social creature. Women can be powerful with their knowledge, experience, and expression. In this era, women can do everything what they want. Not only do housework, women also can do what men do.

Beside that, there are 2 respondents (13\%) who don't believe if lyrics in God Is a Woman by Ariana Grande try to convey that women be a leader of universe. This data strengthen with their assumption if government should not be led by a woman. Being a leader isn't as easy like doing and sharing idea. Being a leader need more wise in making decision. This can be a reference because somehow woman usually bring their emotion fully if she making any decisions.

As we know, conveying the truth is an obligation that must be fulfilled by every human being, both male and female, even if only one value of goodness can be conveyed in the sense that even though his knowledge of goodness is very low. Of course, if humans are going to preach, they must develop according to the times. Therefore, if a woman has knowledge, she is obliged to convey and teach that knowledge to anyone, including men, either in the form of giving lectures, teaching, dialogue through radio and television or writing and other ways, all of which are done with good.

\section{C9:I don't wanna waste no time, yeah C10:You ain't got a one-track mind, yeah \\ C11:Have it any way you like, yeah \\ C12:And I can tell that you know \\ C13:Ain't nobody else can relate \\ C14:Boy, I like that you ain't afraid \\ C15:Baby, lay me down and let's pray \\ C16:I'm tellin' you the way I like it, \\ C17:And I can be all the things you told me \\ C18:(Yeah) \\ C19: When come for me, I keep on flourishing C20:(Yeah) \\ C21:And he see the universe the company C22:It's all in me}

Based on lyrics above, there are 9 respondents (60\%) who believe if lyric God Is a Woman convey that woman can be a preacher. They are people who believe that woman not only do housework. Respondents believe that woman also have a role to convey goodness. In addition, the point of freedom of expression is also the reason why women can also become lecturers. Although the connotation seems unfamiliar, the tenderness of women can be the reason why female lecturers can be accepted in society. Thus data supported with deals that 9 respondents are support gender equality.

While 6 respondents (40\%) who doesn't believe if lyric God Is a Woman convey that woman can be a preacher are respondents who are male. The number of female preachers is still relatively low in the community. The number of female preachers is still relatively low in the community. In addition, if there is a female speaker, the points that are often obtained are not from the message but the cuteness of the speaker itself. So that, female 
preacher are considered to be still less able to master the stage than for the basis why men tend to become preacher.

The role of women is getting narrower because without women life is non-existent. This is understandable because women can give birth. While man don't give birth. Assumption about role of women is getting narrower because without women life is non-existent also indirectly appears in the lyrics God Is a Woman by Ariana Grande below.

C31:I'll tell you all the things you should know C32:So, baby, take my hand, save your soul C33: We can make it last, take it slow, hmm C34:And I can tell that you know I know how I want it, yeah

C35:But you're different from the rest C36:And boy, if you confess, you might get blessed

C37:See if you deserve what comes next

C38:I'm tellin' you the way I like it, how I want it

There are 11 respondents (87\%) who agree if lyric God Is a Woman convey that man cant live without woman. This data is supported because they believe that women aren't weak social creature. Even some of them are male, they are in mature age who already get good knowledge about maturity. They can imagine how painful it is to go through the process of pregnancy until woman have to give birth.

While 4 respondents (13\%) who don't agree if lyric God Is a Woman convey that man cant live without woman are male. This can be based on the belief that men are strong creatures. Man has more physical strength than woman. Man can find food and better job to fulfill their needs.

Based on all explanation above, each reader has different reception. It depends on their gender, social background, level of education, ages, and emotion. Generally, lyrics in Rebel's Girl by Bikini Kill, Partition by Beyoncé, and God Is a Woman by Ariana Grande have their own interpretation. But in developing a literary work, reader reception is a must in a process of giving proud and critics to a literary work.

\section{Values Contained in Rebel's Girl By Bikini Kill, Partition By Beyoncé, and God Is a Woman By Ariana Grande Lyric According To Reader Reception}

Each reader has different interesting values or benefits from the same reading. It is normal for readers to interpret a reading, especially in reading literary works. This also proves that the reader has a role in the process of developing the literary world.

The existence of these various receptions is also interpreted by readers through various responses from readers to the lyrics Rebel's Girl by Bikini Kill, Partition by Beyoncé, and God Is a Woman by Ariana Grande. From the analysis through the distribution of questionnaires, the values that can be taken in the lyrics Rebel's Girl by Bikini Kill, Partition by Beyoncé, and God Is a Woman by Ariana Grande through the reader's responses include freedom of speech, feminism, inner beauty, and sex education.

\section{Freedom of Speech}

Freedom of speech is an important thing in this day. Today, freedom of speech is made in easier way. Currently we live in an era of advanced and developing technology so that everything can be easily conveyed using many media. And if we look at this, it becomes important for the people, especially woman to be aware of the importance of freedom of speech.

In the lyrics Rebel's Girl by Bikini Kill, Partition by Beyoncé, and God Is a Woman by Ariana Grande, there also convey about freedom of speech. Those lyrics clearly convey about what women's desires in all aspects. Rebel's Girl by Bikini Kill convey about woman solidarity and friendship. Partition by Beyoncé convey about woman willingness in social life through beauty. God Is a Woman by Ariana Grande convey about woman can get and do 
what they want freely,

Freedom of speech is important for everyone, where a person can express opinions freely without any restrictions except to spread hatred. Freedom of speech must be done in a smart or appropriate way. One proof is reflected in the lyrics of Rebel's Girl by Bikini Kill through the following lyric:

A10 : When she talks, I hear the revolution

A11:In her hips, there's revolution

A12 : When she walks, the revolution's coming

A13 : In her kiss, I taste the revolution

In the lyrics above, it can be proven that women can make a change in social life. Revolution can also be achieved with the role of women. Through passion, action, and movement, a revolution can arise start from the freedom of sppech.

\section{Feminism}

Feminism can be defined as a women's movement that fights for emancipation or full equality of rights between women and men without discrimination. The essence of feminism is how women should have the same opportunities as men in developing themselves. This can be interpreted in the economic, social, political and educational fields. One proof is reflected in the lyrics of Rebel's Girl by Bikini Kill through the following lyric:
A28 : Love you like a sister always
A29 : Soul sister, rebel girl
A30 : Come and be my best friend
A31 : Will you, rebel girl?
A32 : I really like you
A33 : I really wanna be your best friend
A34:Be my rebel girl

Those lyric not only talk about a friendship, but it also talked about woman activist solidarity. Again, feminist movement isn't only initiated and can be done by a person only. Feminist movement can be done and being reached because there is a struggle among women who wants a same thing

Feminism value that contained in lyrics Rebel's Girl by Bikini Kill, Partition by Beyoncé, and God Is a Woman by Ariana Grande are:

a. A woman has the right to determine the direction of her own life.

b. A woman is able to resist oppression even though it must be against a difficult situation.

c. Men are not gods who can do everything. There are some things that men cannot achieve like a mother's concern for her child. Because basically men grow up to be workers who can't be at home every day.

d. Women can be wise leaders. According to what is contained in lyric God Is a Woman by Ariana Grande that women can also set a rule.

\section{Inner Beauty}

In fact, every woman has an inner beauty. But unfortunately not many women are aware of it and are more busy thinking about the physical beauty that she has. If inner beauty has emerged, then the true beauty of a woman's face will glow up. There is no evidence in the lyrics, but the value can be seen from the process of categorizing responses from readers in responding to a work through a distributed questionnaire.

One of the main keys to exploring inner beauty is to always think positively in every opportunity. For example, a beautiful woman reveals that she is always get anxious, often daydreaming or having bad thoughts can reduce the radiance of one's inner beauty. If inner beauty of women has appeared, it will automatically be accompanied by inner power or self-strength in the form of high self-confidence.

\section{Sex Education}

Sex education is important in today's modern era. Freedom of speech, freedom of access to information, and freedom to love and be loved can also be learned through sex education. Through sex education, young 
people will indirectly realize how to respect the opposite sex.

In addition, through sex education, anyone will be taught how to maintain honor and maintain harmony in a friendship. A woman or a man will not be too brave to commit acts of sexual violence because it deviates from the norms that have been taught previously.

Sex education can also increase a person's sensitivity to the opposite sex to make them more caring. They will more listening into other perception and will easily make friend around.

\section{Conclusion}

From the results of the questionnaire distributed to respondents who are random readers about the lyrics in Rebel's Girl by Bikini Kill, Partition by Beyoncé, and God Is a Woman by Ariana Grande, it can be concluded that the lyrics talk about women's struggles according to reader. Many issue of gender equality can be found inside the lyrics. The answers obtained are variative from each reader who filled out the questionnaire. It is caused by different gender, level of education, and experience. Mostly, respondent at age around $21-47$ years old they already sensitive to gender equality issue. While respondent who still teenager isn't already sensitive about gender equality issue because respondent don't have any enough experience also knowledge about the issue.

There are several values with the lyrics in Rebel's Girl by Bikini Kill, Partition by Beyoncé, and God Is a Woman by Ariana Grande that can be taken from the reader's response. These values are freedom of speech, feminism, inner beauty, and sex education.

\section{Acknowledgment}

This paper is part of the master thesis done by corresponding author in Universitas Sumatera Utara. The writers sincerely address their thankfulness to the teachers and students of SMA Negeri 1 Tanjungbalai, Indonesia who participated in this research. Then, the gratitude goes to Prof. T. Silvana Sinar, Ph.D. and Prof. Dr. Ridwan Hanafiah, M.A. who sincerely supervised the writer during her study.

\section{References}

Adi, Tri Nugroho. (2011). Mengkaji Khalayak Media Dengan Penelitian Resepsi. (Vol. 8, Issue 1).

Endraswara, Suwardi. (2008). Metodologi Penelitian Sastra. Epistemologi, Model, Teori dan Aplikasi (Edisi Revisi). Yogyakarta: MedPress (Anggota IKAPI)

Iser, Wolfgang. (1980). Act of Reading: A Theory of Aesthetic Response. London: Routledge.

Jauss, Hans Robert. (1982). Aesthetic Experience and Literary Hermeneutics. Minneapolis: University of Minnesota Press

Kamar, Uyam. (1981). Seni, Tradisi, Masyarakat. Jakarta: Penerbit Sinar Harapan.

Klarer, Mario. (2004). An Introduction to Literary Studies. London and New York: Routledge

Kusumawati, Desi. (2019). Estetika Resepsi Dalam Novel Cantik Itu Luka Karya Eka Kurniawan; Kajian Hans Robert Jauss. Surabaya: Universitas Surabaya

Lestrai, Dwi. (2019). Analisis Resepsi Sastra Terhadap Novel Banat Ar Riyadh Karya Rajaa Alsanea. Salatiga: Institut Agama Islam Negeri Salatiga.

Nurgiyantoro, Burhan. (1995). Teori Pengkajian Fiksi. Yogyakarta: Gajah Mada Media Press

Nurkhayati, Lusi. (2018). Analysis of Spike Lee's Malcolm X (1992): The Intrinsic Aspects and the Reader's Responses to the Movie. Semarang: Universitas Muhammadiyah Semarang. 
Pradopo, Rachmat Djoko. (2012). Beberapa Teori Sastra, Metode Kritik, dan Penerapannya. Yogyakarta: Pustaka Pelajar

Sapardi, Djoko. (2010). Puisi Indonesia Sejarah dan Kritik. Jakarta: Pustaka Obor Indonesia

Segers, R.T. (1978). Recepti - Esthetika. Netherlands: Huis aan dedrie grachten.

Sugiyono. (2008). Metode Penelitian Kuantitatif, Kualitatif, dan R\&D. Bandung: Alfabeta.

Teeuw, A. (2017). Sastra dan Ilmu Sastra. Bandung: PT Dunia Pustaka Jaya.

Tyson, Lois. (2006). Critical Theory Today. London: Routledge.

Wibowo, Satriya. (2018). You're Never Walk Alone Song: Reader Response Analysis. Yogkarta: Universitas Islam Negeri Sultan Kalijaga Yogyakarta.

https://text-id.123dok.com/document/ oy8nmr05y-hans-robert-jauss-horisonharapan-teori-sastra-1-teori-sastra-1teori-sastra-1-teori-sastra-1.html

http://ukonpurkonudin.blogspot. com/2010/06/teori-resepsi-sastra-jauss. html 